\title{
XXTH-CENTURY THEORIES OF LANGUAGE: AN EPISTEMOLOGICAL DIAGNOSIS
}

\section{Introduction.}

This article is intended as a study in the methodology and epistemology of linguistics, a field which developed out of theoretical linguistics in the past thirty years. Methodology and epistemology (or philosophy) ${ }^{1}$ of linguistics can be subsumed under the general domain of "philosophical linguistics" (cfr. Kasher - Lappin 1977), which also includes a theory of meaning and reference, a theory of linguistic (or, more generally semiotic) communication, and - in some cases - a formalization of linguistic subsystems. The specific contribution of methodology and epistemology of linguistics lies in the definition of the object of linguistics, in the determination and justification of its research techniques, in the appreciation of its results with respect to a broader field of investigation, in the reflection on the nature, status, and variability of approaches to language. ${ }^{2}$

The history of general linguistics (which is still an ill-defined concept) since the beginning of this century shows that the basic notions - such as "language", "grammar", "(linguistic) meaning", "(linguistic) structure" - underwent a radical change in intension and extension, and have been focused upon from different points of view, in variegated perspectives (cfr. Swiggers 1989). It would be presumptuous to analyse the various "transformations of linguistics" 3 in this article; our aim here is to offer some ge-

1 I am taking epistemology here in its "correlative" acceptation (viz. "epistemology of -"; cfr. the use of épistémologie in French), and not in its "absolute" acceptation (epistemology as theory of knowledge), which has been the most common one in Anglo-Saxon philosophy. The advantage of taking "epistemology" in its correlative meaning is that it allows us not only to bridge the gap between English and French usage (see, e.g., Dominicy ed. 1991), but also to account for the fact that "epistemology of linguistics" is also about the theory of linguistic knowledge. The epistemologist's task is to define the kind of knowledge aimed at (and, ideally, attained) by (the application of) a particular theory within a particular domain, and to compare theories which are intended to cover an almost identical extensional field.

2 For a conspectus of recent theories of linguistics, see Moravcsik - Wirth (eds. 1980), Sells (1985; cfr. Swiggers 1987), Droste - d'Hulst (eds. 1987; cfr. Swiggers 1988), Droste - Joseph (eds. 1991).

3 I am borrowing this term from Benveniste (1966), the first part of which bears the title "Transformations de la linguistique". Benveniste's characterization of the development of general 
neral reflections on a few aspects of these transformations, serving as a preliminary to a more comprehensive "historical epistemology"4 of modern linguistics.

\section{Sign-centered theories of linguistics.}

The courses in general linguistics which Saussure taught at the University of Geneva between 1906 and 1911, and which provide the substance of the posthumously published Cours de linguistique générale edited by Charles Bally and Albert Sechehaye, can be seen as the unfolding project - which can be traced back to the early $1890 \mathrm{~s}$ - of defining the field of general linguistics, and of formulating the principes généraux of the science of language. Saussure's endeavour cannot be isolated from its intellectual context, in which the discussion on the nature and classification of sciences played a crucial role. In 1898 Edmond Goblot, in his Essai sur la classification des sciences, remarked that the "moral sciences" had not yet fixed their object, nor their principles and methods. These sciences, aspiring to become "positive", show a tendency to depart from their empirical grounds, and to idealize their objects: in this they manifest what Goblot calls "un dualisme logique". Adrien Naville, in his Nouvelle classification des sciences (1901), divides the sciences into three kinds: theorematical, historical, and canonical. The first kind is concerned with possibilities (constrained by laws), the second with realities, the third with the notion of "good" (or "useful"). Within the first kind Naville includes mathematics, physics (subsuming biology, mechanics, chemistry), and psychology (and sociology). The logically prior science within the theorematical sciences is nomology, the object of which is the notion of $l a w^{5}$. Saussure's linguistic itinerary can be seen as a constant search for the elaboration of a nomology of linguistics, structured in an axiomatic way.

linguistics involves a distinction between three distinct phases (a philosophically oriented approach of language categories; a historically oriented approach of language forms; a syntactic analysis of the "intrinsic reality" of language). At the same time Benveniste (1966: 16-17) outlined various possibilities of further development. For a stimulating overview of "changing perspectives" in modern linguistics, see Chomsky $(1986 \mathrm{a}, \mathrm{b})$. For a penetrating analysis of phonological theories, see Anderson (1985). For global epistemological analyses, see Dougherty (1973) and Itkonen (1978, 1984).

4 Following the approach outlined by Canguilhem (1983) and Guéroult (1979).

5 See Naville (1901: 40-41): "Son développement dépend en un sens de celui des sciences qui viennent après elle dans la série; elles naissent et grandissent avant la nomologie et lui fournissent des matériaux dont l'idée pure de loi doit être dégagée. Mais aucune autre sience de loi, pas même les mathématiques, ne peut atteindre son achèvement et sa perfection systématique aussi longtemps que la nomologie n'y sera pas elle-même parvenue. Les sciences plus complexes, comme la biologie et la sociologie, ne sortiront de l'état chaotique où elles sont encore aujourd'hui que par une compréhension meilleure de la nature de l'objet de leurs recherches, c'est-à-dire par une meilleure définition de l'idée de loi". 
Although Saussure arrived only very late (in May 1911) at the distinction between signifie and signifiant, he soon saw that the specific nature of linguistics - or of the fait linguistique - lies in the interplay between sound and sense, an interplay which is concretized, in a creative (and oppositive) way, in the linguistic sign:

"On a discuté pour savoir si la linguistique appartenait à l'ordre des sciences naturelles ou des sciences historiques. Elle n'appartient à aucun des deux, mais à un compartiment des sciences <qui, s'il n'existe pas, devrait exister sous le> nom de sémiologie, c'est-à-dire science des signes ou étude de ce qui se produit lorsque l'homme essaie de signifier sa pensée au moyen d'une convention nécessaire. $<$ Parmi tous les systèmes sémiologiques $>$ le système sémiologique "langue" est le seul (avec l'écriture) qui ait eu à affronter cette épreuve de se trouver en présence du Temps, qui ne se soit pas simplement fondé de voisin à voisin par mutuel consentement, mais aussi de père en fils par impérative tradition et au hasard de ce qui arriverait en cette tradition, chose hors de cela inexpérimentée <non connue ni décrite>. Si l'on veut, la linguistique est donc une science psychologique en tant que sémiologique, mais les psychologues n'ont jamais fait intervenir le TEMPS dans leur sémiologie. Ce fait qui est le premier qui puisse exciter l'intérêt du philosophe reste ignoré des philosophes: aucun d'eux n'enseigne ce qui se passe dans la transmission d'une sémiologie. Et ce <même> fait accapare en revanche tellement l'attention des linguistes que ceux-ci en sont à croire <pour cela> que leur science est historique ou éminemment historique, n'étant rien d'autre que sémiologique: par là complètement comprise d'avance dans la psychologie, à condition que celle-ci voie de son côté qu'elle a dans la langue un objet s'étendant à travers le temps, et la forçant de sortir absolument de ses spéculations sur le signe momentané et l'idée momentanée" (Saussure [Engler ed.] 1968-1974: vol. II, fragment 3342.1).

Saussure's choice of the linguistic sign as the axiomatically central concept of linguistics not only entailed the "semiological" status of linguistics, but it also implied the dichotomies elaborated upon in the Cours: the langue/parole distinction within the "facultas signatrix" (corresponding to the systematic insertion of signs within the social context of language, and to its expressive realization in individual speech); the synchrony/diachrony distinction (corresponding to the opposition between the status of elements used as termes d'un système, and the chronological, non-systemic, link between (parts of) systems); the distinction between the associative and syntagmatic axes (corresponding to static versus dynamic differentiality of signs) ${ }^{6}$.

Saussure's theory of language ${ }^{7}$ is based on an epistemology which is neither instrumentalist nor realist: language is defined in terms of a phenomenological conceptualism, stressing the creative articulation of linguistic entities, fulfilling a social function. These entities are not sentences; the reason why Saussure discards sentences as a unit of analysis is not so much that they belong to parole, but that there is no property in

In fact, one can say that the associative axis concerns the caractère différentiel of the sign as a bifacial unity (signifiant/signifié), whereas the syntagmatic axis concerns the oppositive nature of signs taken on their own. 
common to them ${ }^{8}$. The linguistic sign is a unit of both langue and parole, and it invariably presents a signifiant/signifié structure?.

Saussure's choice of the linguistic sign as the central notion of his language theory is paralleled in Vendryes's (1921) distinction between form and meaning, and in Sapir's (1921) distinction between form and content (cfr. Swiggers 1991a). Both authors, however, present us with an extension of Saussure's theory of language. Vendryes's distinction between form and meaning is not only relevant to the nature of the linguistic sign, but it also pervades the entire linguistic system, viewed as a complex distribution of relationships between form-units and meaning-units. A sentence results of the synthesis of elements which are the (analytical) expression of content-representations and of the relations between these. Sapir's contribution lies in the typological elaboration of the relationship between form and (conceptual) content. Language, the symbolic expression of experience, manifests a relationship between matter and form: only the latter is relevant to the linguist, and more particularly insofar as linguistic form has no direct link with a particular function. The asymmetry between form and function explains why Sapir distinguishes between grammatical processes and grammatical concepts: the former correspond to a view "from form to function", the latter to a view "from function to form" (or even from function to function). Typology therefore has a double role in Sapir (1921): it shows the multiple relationship between form and function within one language, and it manifests the variance of form/function-coupling among languages. In Sapir's typological table (1921: 150-151) this corresponds to the basic distinction between the "capital" (conceptual) types of languages (Simple Pure-Relational, Complex Pure-Relational, Simple Mixed-Relational, Complex Mixed-Relational) and the process-subtypes (indicated by smaller letters: a, b, c, d) within one language (cfr. Swiggers 1993).

Vendryes (1921) and Sapir (1921) were not so much preoccupied with defining the field of general linguistics, nor with determining its axiomatically central units. In fact,

See Saussure (1916: 152): "Une théorie assez répandue prétend que les seules unités concrètes sont les phrases: nous ne parlons que par les phrases, et après coup nous en extrayons les mots. Mais d'abord jusqu'à quel point la phrase appartient-elle à la langue? Si elle relève de la parole, elle ne saurait passer pour l'unité linguistique. Admettons cependant que cette difficulté soit écartée. Si nous nous représentons l'ensemble des phrases susceptibles d'être prononcées, leur caractère le plus frappant est de ne pas se ressembler du tout entre elles. Au premier abord on est tenté d'assimiler l'immense diversité des phrases à la diversité non moins grande des individus qui composent une espèce zoologique; mais c'est une illusion: chez les animaux d'une même espèce les caractères communs sont bien plus importants que les différences qui les séparent; entre les phrases, au contraire, c'est la diversité qui domine, et dès qu'on cherche ce qui les relie toutes à travers cette diversité, on retrouve, sans l'avoir cherché, le mot avec ses caractères grammaticaux, et l'on retombe dans les mêmes difficultés" (for the different versions in the students' notes, see Saussure [Engler ed.] 1968-1974: vol. I, 240).

9 Saussure's view is subject to criticism here: it is not clear, given the absence of a theory of morphemes in the Cours, whether Saussure would equate morpheme with sign; if this were the case, two problems arise: (a) that of zero signifiants (absence of linearity!), (b) that of signifiants without signifié (e.g., "interfixes" and linking morphemes of morphophonemic units). 
their epistemological outlook was less "phenomenological" than Saussure's in that they identified some "real" properties of language structure as being the solid foundations for a theory of language. In addition to this, both authors differed from Saussure on the issue of the autonomy or non-autonomy of linguistics.

\section{Level-oriented theories of linguistics.}

A major breakthrough in the theory of language was achieved by the elaboration of a level-analysis of languages. The concept of level-analysis implied two major axioms:

(a) units of description are defined with respect to a level of analysis (as such, two elements can be analysed as distinct on the phonemic level, but as non-distinct on the morphophonemic level);

(b) the study of each level involves the application of a particular technique and notation.

Basically, these insights were on line with Saussure's idea that linguistic units are the results of analysis, and are not given, and with its implication that units are ultimately defined by the analytical determination of their oppositive nature ${ }^{10}$. But levelanalysis makes it possible to study language as a system of recursive combinations involving finite sets of elements:

"The number of orders of phonemes in the morphemes and words of a language is a sub-multiple of the number of possible orders (...)

The number of constructions in a language is a small sub-multiple of the number of forms (...)

Each position in a construction can be filled only by certain forms" (Bloomfield 1926: 157-158).

These were postulates of a "scientifically" conceived linguistics, along the lines of a methodology which can be labelled "physicalism", "behaviourism", or "operationalism" ${ }^{\prime 1}$. The purpose is to account for the possible combinations of elements and to use

10 See Saussure (1916: 153): "Mais de même que le jeu d'échecs est tout entier dans la combinaison des différentes pièces, de même la langue a le caractère d'un système basé complètement sur l'opposition de ses unités concrètes. On ne peut ni se dispenser de les connaître, ni faire un pas sans recourir à elles; et pourtant leur délimitation est un problème si délicat qu'on se demande si elles sont réellement données. La langue présente donc ce caractère étrange et frappant de ne pas offrir d'entités perceptibles de prime abord, sans qu'on puisse douter cependant qu'elles existent et que c'est leur jeu qui la constitue. C'est là sans doute un trait qui la distingue de toutes les autres institutions sémiologiques "(for the different versions in the students' notes, see Saussure [Engler ed.] 1968-1974: vol. I, 241-242).

11 See Bloomfield (1933: 509): "The methods and results of linguistics, in spite of their modest scope, resemble those of natural science, the domain in which science has been most successful. It is only a prospect, but not hopelessly remote, that the study of language may help us toward the understanding and control of humans events"; and Bloomfield (1939: 11): "... widespread and deep-seated errors in supposedly scientific views of human behaviour rest upon ... failure to 
the tremendous selectivity of language to describe how language carries messages. The focus on selectivity led to discoveries of correlations between meanings and selections of forms. As Bloomfield pointed out, it frequently happens that when we do not content ourselves with the explanation "that something is due to meaning, we discover that it has a formular regularity or 'explanation'" (Harris 1970: 785).

Selectivity also is the basis of Bloomfield's theory of meaning (cfr. Bloomfield 1933: 139-157; Bloomfield 1939). Contrary to a widespread belief - based on unfamiliarity with Bloomfield's work - he wrote more about meaning then most linguists of his time. For Bloomfield, meaning is not just a function of a speech utterance; it is a relation between the speaker's stimulus, the utterance, and the hearer's reception and response (Bloomfield 1939: 18). "The term 'meaning', which is used by all linguists, is necessarily inclusive, since it must embrace all aspects of semiosis that may be distinguished by a philosophical or logical analysis: relations, on various levels, of speech forms to other speech-forms, relations of speech-forms to non-verbal situations (objects, events, etc.), and relations, again on various levels, to the persons who are participating in the act of communication" (Bloomfield 1939: 18; see also Bloomfield 1933: 77).

Bloomfield's work - and that of some of his followers, e.g. Z.S. Harris and Ch. F. Hockett - has been crucially important in two ways:

(a) it has shown the importance of refining techniques for linguistic description, and has thus led to a highly controllable account of how levels can be distinguished, and how units can be categorized within a homogeneous description of speech events;

(b) it has shown that for a given data equivalent procedures, all of them uniform and consistent, can be set up. As a consequence, no ontological import should be attributed to the descriptive model: the structure of the description is not identical with the structure of the descriptum; at the most, there is a correlative homomorphy.

Bloomfield's theory of language is coupled with an instrumentalist epistemology of linguistics, and of science in general (cfr. Hiż - Swiggers 1990). Bloomfield welcomed the physicalism and mechanism of Carnap and Neurath, their program for a unified language and method of science. A scientific description of language should be made in a language of science in general. Bloomfield was convinced of the unity of science, as a social and linguistic process, and this explains why he speaks of scientific practice, of the branches of science, and of the "great vocabulary of science" (Bloomfield 1939: $20,49,55)$. The discourse construed by the scientist is basically of two types. In the first type the correctness of a discourse is bound only by the verbal agreements on which it is based. This type of discourse, as far as it is limited to verbal activity, in fact does not constitute a science. This would be the case of mathematics.

distinguish between linguistic and nonlinguistic events, upon confusion of the biophysical and the biosocial aspects of language and its subsidiaries, and above all, upon a habit of ignoring the linguistic parts of a sequence [= stimulus, speech act, reception, response] and then calling upon metaphysical entities to bridge the gap". 
Bloomfield adopted Carnap's view that uninterpreted mathematics is without factual content; it is a result of agreements on the use of words. In mathematics certainty results from its nonfactuality. Applied mathematics is factual, but no more certain than the science to which it is applied. "The invention and skilful manipulation of speechforms is not a science, but a skill, craft or art" (Bloomfield 1939: 56). The other type of scientific discourse involves, besides the verbal agreements, the biosocial agreements affecting the reception of the discourse by a community: Bloomfield refers to it as "publicity". "Unique personal or communal behavior figures in science as an object, which may be observed like any other; but it does not figure as a part of scientific procedure" (Bloomfield 1939: 47). The language of scientific procedure (as public activity) is a language stripped of the private feelings, attitudes, and connotations attached to linguistic forms by the participants: "each participant burns his own smoke" (Bloomfield 1939: 47).

\section{Transformation-oriented theories of linguistics.}

The instrumentalist view of language has been refined in work on phonology and morphology by Harris, Hockett, Nida, Swadesh, Voegelin; it has focused on problems of segmentation and classification, which - no linguist would disagree on this - remain essential to any type of linguistic work. The upper level of this descriptive work has mostly been that of morphemes; attempts at extending the taxonomy to syntagms can be found in Wells (1947), Harris (1951: chapter 18), Hockett (1958: chapters 17-31), and Pike (1967: chapters 11-14), but one cannot say that parallel to the procedures for establishing paradigms of morphemes there were procedures for establishing paradigms of phrasal relationships.

Zellig Harris's work in the $1950 \mathrm{~s}^{12}$ and Chomsky's transformational grammar aimed at offering this extension of the structuralist methodology to syntactic relationships; the implications of this was that syntactic analysis was autonomous (a view held by Chomsky up to the 1970s), and could be kept separate from semantics, as well as from prosodical and intonational phenomena. The autonomous conception of syntax has been severely criticized for its neglect of the semantic component; personally I regret as much ${ }^{13}$ the discrimination of the suprasegmental level, a fact which still has to be deplored in the most recent versions of generative grammar.

The autonomy of syntax - abandoned in the Government and Binding Model ${ }^{14}$ was a strong claim, which had a positive and a negative consequence. The positive one

12 Harris's foundation-laying papers from the 1950 s on transformations and discourse analysis are collected in Harris (1970).

13 Or even more, since the relevant semantic relationships can be recovered from (larger sets of) distribution.

14 The Government and Binding model may seem a more powerful model than any of its generative/ 
was that it could be shown that relationships extend beyond linear sequences and substitutional slots; the negative one was that this gave way to highly tentative conclusions, which in my opinion are still in need of proof. The eagerness to formulate such conclusions should be seen in the light of Chomsky's interest in metatheoretical problems ${ }^{15}$, starting with discussions concerning the adequacy of grammars and of taxonomic techniques, and leading to claims concerning the nature of linguistic knowledge, the status of grammar, and the place of linguistics. Chomsky's passionate and patient search for a theory of language has not yet received a detailed epistemological analysis ${ }^{16}$, and one should bear in mind the fact that Chomsky feels that linguistics still has to undergo "something like a Copernican or Galilean revolution". The issues of the social impact of Chomsky's work, of its novelty, of its position with respect to older and contemporary theories, of its strategies (for a case study, see Swiggers 1995) should also be addressed in such an investigation, which cannot exclude the social history and the intellectual context of generative grammar. But what should be addressed in the first place are the following questions, which are essential to Chomsky's practice of linguistics, and to his conception of grammar and language; each of these offers ample matter for debate, because it seems to me that Chomsky has not yet offered a cogent argumentation on these issues.

(1) Chomsky claims that linguistic competence, studied in depth, can be studied as a conceptually innate structure. While this position justifies the use of the introspective method, viz. the appeal to the ideal speaker's intuitions, it is not clear $(a)$ what is precisely innate (what type of structure, or what type of principles), $(b)$ why in such a view so much stress should be laid on the "empirical" nature of the investigation, (c) why grammatical rules are so diverse, and at times so undetermined ( $c$ is both a problem for universal grammar, and for the categorial content of any "private" grammar) ${ }^{17},(d)$ how an operational language concept can be extracted from the concept of I-Grammar.

transformational predecessors, but it is, on the other hand, a conceptually heterogeneous frame, in which for instance the theory of thematic roles is an oddity. As a general problem I see the opaque relationship between what Chomsky calls Logical Form and S-Structure.

15 See Hymes and Fought's (1981: 242-243) remarks on Chomsky's metatheoretical expansion (or, better, deepening) of Harrisian methodology: "In short, what Chomsky has done is to retain the scope of linguistic theory established by the Bloomfieldians and particularly in his case by Harris formal linguistic structure - and, while deepening the concept of structure itself, invest theory of such scope with utmost significance. Put in other, and quite appropriate terms, the relation between methodological form and substantive content in Chomsky's work is consistently interpretive (...) Chomsky did not so much add theory to methodology, as find theory in methodology".

16 For an analysis of Chomsky's earlier views, Lyons (1970: see Hymes 1972), Hiorth (1974), Saporta (1978) and Harman (ed. 1982) are very useful. For Chomsky's recent views, see Chomsky (1968a, 1988) and Kasher (ed. 1991). The latter volume contains contributions written "from inside the generative model" (contrary to Harman ed. 1982). For a brief, but penetrating analysis of Chomsky's conception of "language", see Matthews (1990).

17 On the issue of "private" vs. "socialized" grammar (or the Wittgenstein/Kripke - Chomsky debate), see Swiggers (1987b). 
(2) Chomsky has repeatedly insisted (recently, in Chomsky 1987) on the necessity of construing a grammar which has psychological reality. But the content of the concept of "psychological reality" has remained vague (for harsh criticism, see Derwing 1973); reference to the "modularity of mind" (see Fodor 1983) may seem an easy wayout, but it is in fact a dead end: (a) one can hardly deny that in a concrete discursive fragment (involving, e.g., cases of anaphorization, cataphorization, deletion of forms, switching of deictic elements, as well as phenomena such as presupposition, implication, ellipsis, etc.) the human mind produces and retrieves information synthesized in decodable structures: the question then is whether modularity is not an unrealistic explanans; $(b)$ a modular grammar (involving X-bar theory, theta theory, binding theory, case theory, control theory, bounding theory) may be easier to "control" in terms of descriptive efficiency, but then we would like to know how the (language faculty in the) mind controls these modules, and what kind of creative control there can be.

(3) This brings us to a third problem. Chomsky has, since the early sixties, stressed the creative nature of language. He has however, never shown in what way linguistic creativity is different from (or is more than) analogical construing. Chomsky (1986a: 11-12) claims that analogy is not a sufficient explanation for "Plato's problem", but his argument is extremely weak: $(a)$ he does not consider the full range of analogical constructions (not to speak of the sets out of which analogies could be construed); $(b)$ the type of proportional analogy he seems to use, involves a wrongly construed proportion (see Itkonen 1991); (c) he does not show in what way analogy would be a deficient explanation. Of course, an appeal to analogy as an explanatory principle would urge a revision of ( $\left.a^{\prime}\right)$ the notion of ideal speaker (correlated with grammaticality judgments), (b') the notion of internalized grammar (coupled with the issues of modularity and of innate universal principles), (c') the notion of "rule" (correlated with Universal Grammar, and with grammaticality judgments) ${ }^{18}$.

(4) Chomsky has, consequently, maintained his claims about the universality of grammatical principles (for a critical view, see Hagège 1976). Integrating cross-linguistic research, the Government and Binding model has set up a "parametric(al) syntax"; while this may be an interesting prototypological device, it cannot conceal the following problems: $(a)$ it makes little sense to put up explanatory parameters if so much taxonomical work has still to be done (cfr. Gross 1979$)^{19}$; (b) a parametrical option should

18 In addition Chomsky leaves unmentioned the fact that structuralist accounts of analogy involve a not uninteresting recognition of linguistic creativity; see, e.g., Bloomfield (1933: 275-276): "A grammatical pattern (sentence-type, construction, or substitution) is often called an analogy. A regular analogy permits a speaker to utter speech-forms which he has not heard; we say that he utters them on the analogy of similar forms which he has heard (...) The regular analogies of a language are habits of substitution (...) When a speaker utters a complex form, we are in most cases unable to tell whether he has heard it before or has created it on the analogy of other forms". On the notion of "rule", and its link with explanatory adequacy, Quine's reflections are still worth meditating (Quine 1972).

19 For a similar criticism see my remarks (Swiggers 1984) on Chomsky's account of control-structures, which are explained by reference to the "nature" of the head verb (see Chomsky 1982: 75). 
be related to a structural invariant (what would be the invariant of the options concerning a fixed or a free word order ?); (c) any typology which starts from taking the "familiar" case as the "normal" (or "configurational" ...) one, is condemned to step on its own tail.

\section{Conclusion.}

This paper has focused on some aspects of linguistic theory in its relation to general epistemology and epistemology of linguistics. The changes which characterize XXth-century linguistics have affected the relationship between language and grammar (the latter being more and more conceived as a theory of language structure or even as a theory of mind about internalized language; cfr. Chomsky 1986a), as well as the relationship between linguistic description and reality (also reality of knowledge). There has been, in retrospect, much more continuity in methodology than in epistemology: much of Chomsky's earlier work (roughly up to the 1970s) has been, from the point of view of methodology, in continuity with Bloomfieldian (and more particularly Harris's) linguistics. But Chomsky's objective realism (cf. Blackburn 1984: 27-29), and his insistence on the psychological reality not of units but of structures (and their relationships), have led to a totally different view of both grammar and variance ${ }^{20}$ (distinct from sociolinguistic variation).

Chomsky's enterprise has gained in technicality; logical coherence is, however, only a prerequisite, but not a guarantee of adequacy. Today its strongest opponent is a cognitive approach (cfr. Lakoff 1986; Langacker 1986, 1987, 1990; Rudzka-Ostyn ed. 1988) which rejects the modular conception of mind, and which focuses on (prototypical) semantic relationships (Chomsky's approach has always been a basically "syntacticist" one). "Internalized realism" vs. "externalized realism" seems, today, the basic controversy in linguistic theorizing, as well as in the theory of knowledge (see Burge 1986a,b, 1988; Davidson 1987, 1991): this should, however, not make us forget that much more work needs to be done on the level of description. And whether one subsumes this work under an instrumentalist epistemology or not, one thing is clear: language and its structure - the object of grammar - cannot be isolated from communication, and more specifically of information (see Harris's foundation-laying work: 1988, 1991). The latter notion is essentially a structural one: it corresponds to both organizational patterns of language(-types), and the individual (and diachronically as well as socially variable) exploitation of these patterns, in function of communicative needs. In the light of this one feels that linguistic theory will have to elaborate an adequate, and more comprehensive, epistemology. It also seems that this epistemology should take a new look at analogy, as a linguistic and a cognitive process. 


\section{References}

Anderson, S.R. 1985. Phonology in the Twentieth Century. Theories of rules and theories of representations. Chicago: The University of Chicago Press.

Benveniste, E. 1966. Problèmes de linguistique générale. Paris: Gallimard.

Blackburn, S. 1984. Spreading the Word. Groundings in the Philosophy of Language. Oxford: Clarendon Press.

Bloomfield, L. 1926, "A Set of Postulates for the Science of Language". Language 2. 153-164.

Bloomfield, L. 1933. Language. New York: Holt.

Bloomfield, L. 1939. Linguistic Aspects of Science (International Encyclopedia of Unified Science, vol. I, number 4). Chicago: The University of Chicago Press.

Burge, T. 1986a. "Individualism and Psychology". The Philosophical Review 95. 3-45. Burge, T. 1986b. "Intellectual Norms and Foundations of Mind". The Journal of Philosophy 83. 697-720.

Burge, T. 1988. "Individuation and Self-Knowledge". The Journal of Philosophy 85. 649-663.

Canguilhem, G. 1983. Etudes d'histoire et de philosophie des sciences. Paris: Vrin.

Carnap, R. 1928. Der logische Aufbau der Welt. Berlin-Leipzig: Meiner.

Chomsky, N. 1982. Lectures on Government and Binding. The Pisa Lectures. Dordrecht: Foris. [First ed., 1981]

Chomsky, N. 1986a. Knowledge of Language: Its Nature, Origin, and Use. New York: Praeger.

Chomsky, N. 1986b. "Changing Perspectives on Knowledge and Use of Language". Leuvense Bijdragen 75. 1-71.

Chomsky, N. 1987. Language in a Psychological Setting. Tokyo: Sophia Linguistica.

Chomsky, N. 1988. Language and Problems of Knowledge. Cambridge, Mass.: The MIT Press.

Davidson, D. 1987. "Knowing One's Own Mind". Proceedings and Addresses of the American Philosophical Association 1987. 441-458.

Davidson, D. 1991. "Epistemology Externalized". Dialectica 45. 191-202.

Derwing, B.L. 1973. Transformational Grammar as a Theory of Language Acquisition. Cambridge: Cambridge University Press.

Dominicy, M. ed. 1991. Epistémologie de la linguistique (= Histoire, Epistémologie, Langage 13:1).

Dougherty, R.C. 1973. "A Survey of Linguistic Methods and Arguments". Foundations of Language 10. 423-490.

Droste, F. - d'Hulst, Y. eds. 1987. Nuove prospettive nella linguistica contemporanea. Padova: CLEP.

Droste, F. - Joseph, J.E. eds. 1991. Linguistic Theory and Grammatical Description. Amsterdam: J. Benjamins.

Engler, R. 1983. "Das sprachliche Zeichen bei Saussure, Bally, Sechehaye", Zeitschrift für Phonetik, Sprachwissenschaft und Kommunikationsforschung 36. 533-542.

Fodor, J.A. 1983. The Modularity of Mind. Cambridge, Mass.: The MIT Press.

Gadet, F. 1987. Saussure: une science de la langue. Paris: P.U.F. 
Goblot, E. 1898. Essai sur la classification des sciences. Paris: Alcan.

Gross, M. 1979. "On the Failure of Generative Grammar". Language 55. 859-885.

Guéroult, M. 1979. Dianoématique II: Philosophie de l'histoire de la philosophie.

Paris: Aubier-Montaigne.

Hagège, C. 1976. La grammaire générative. Réflexions critiques. Paris: P.U.F.

Harman, G. ed. 1982. On Noam Chomsky. Critical Essays. Amherst: The University of Massachusetts Press. [Second edition]

Harris, Z.S. 1951. Methods in Structural Linguistics. Chicago: The University of Chicago Press.

Harris, Z.S. 1970. Papers in Structural and Transformational Linguistics. Dordrecht: Reidel.

Harris, Z.S. 1988. Language and Information. New York: Columbia University Press. Harris, Z.S. 1991. A Theory of Language and Information. Oxford: Clarendon Press.

Hiorth, F. 1974. Noam Chomsky, Linguistics and Philosophy. Oslo: Universitetsforlaget.

Hiż, H. - Swiggers, P. 1990. "Bloomfield, the Logical Positivist". Semiotica 79. 257270.

Hockett, Ch. F. 1958. A Course in Modern Linguistics. New York: Macmillan.

Holdcroft, D. 1991. Saussure: Signs, Systems, and Arbitrariness. Cambridge: Cambridge University Press.

Hymes, D. 1972. review of Lyons 1970. Language 48. 416-427.

Hymes, D. - Fought, J. 1981. American Structuralism. The Hague: Mouton.

Itkonen, E. 1978. Grammatical Theory and Metascience. Amsterdam: J. Benjamins.

Itkonen, E. 1984. Causality in Linguistic Theory. London: Croom Helm.

Itkonen, E. 1991. "What is Methodology (and History) of Linguistics Good for, Epistemologically Speaking?". Dominicy ed. 1991. 51-75.

Kasher, A. ed. 1991. The Chomskyan Turn. London: Blackwell.

Kasher, A. - Lappin, S. 1977. Philosophical Linguistics. An introduction. Kronberg:

Scriptor Verlag.

Lakoff, G. 1986. Women, Fire, and Dangerous Things. Chicago: The University of Chicago Press.

Langacker, R.W. 1986. "An Introduction to Cognitive Grammar". Cognitive Science 10. 1-40.

Langacker, R.W. 1987. Foundations of Cognitive Grammar. Vol. 1: Theoretical Prerequisites. Stanford: Stanford University Press.

Langacker, R.W. 1990. Concept, Image, and Symbol. The cognitive basis of grammar. Berlin-New York: Mouton de Gruyter.

Lyons, J. 1970. Noam Chomsky. New York: Viking; London: Fontana.

Matthews, P.H. 1990. "Language as a Mental Faculty: Chomsky's Progress". N.E. Collinge ed., An Encyclopaedia of Language, 112-138. London: Croom Helm.

Moravcsik, E. - Wirth, J.R. eds. 1980. Current Approaches to Syntax. (Syntax and Semantics, vol. 13). New York: Academic Press.

Naville, A. 1901. Nouvelle classification des sciences. Etude philosophique. Paris: Alcan. 
Pike, K.L. 1967. Language in Relation to a Unified Theory of the Structure of Human Behavior. The Hague: Mouton.

Quine, W.V.O. 1972. "Methodological Reflections on Current Linguistic Theory". D.

Davidson - G. Harman eds., Semantics of Natural Language, 442-454. Dordrecht: Reidel.

Rudzka-Ostyn, B. ed. 1988. Topics in Cognitive Linguistics. Amsterdam: J. Benjamins. Sapir, E. 1921. Language. An introduction to the study of speech. New York: Harcourt, Brace \& Co.

Saporta, S. 1978. "An Interview with Noam Chomsky". Linguistic Analysis 4. 301-319. Saussure, F. de. 1916. Cours de linguistique générale. Publié par Charles Bally et Albert Sechehaye, avec la collaboration de Albert Riedlinger. Paris - Lausanne: Payot.

Saussure, F. de. 1968-1974. Cours de linguistique générale. Edition critique par Rudolf Engler. Wiesbaden: Harrassowitz.

Sells, P. 1985. Lectures on Contemporary Syntactic Theories. An introduction to Government-Binding Theory, Generalized Phrase Structure Grammar, and LexicalFunctional Grammar. Stanford: Center for the Study of Language and Information.

Swiggers, P. 1984. "Remarques épistémologiques sur la grammaire générative". Lingvisticae Investigationes 8. 429-435.

Swiggers, P. 1987a. review of Sells 1985. Bulletin de la Société de Linguistique de Paris 82:2. 104-107.

Swiggers, P. 1987b. "Wittgenstein - Kripke - Chomsky". Tijdschrift voor Filosofie 49. 71-80.

Swiggers, P. 1988. review of Droste - d'Hulst eds. 1987. Revue de Linguistique romane 52. 479-481.

Swiggers, P. 1989. "Linguistics". International Encyclopedia of Communications, vol. II, 431-436. New York-Oxford: Oxford University Press.

Swiggers, P. 1991a. "Note sur la linguistique générale en 1921-1922. Avec l'édition de deux lettres de Joseph Vendryes à Edward Sapir". Beiträge zur Geschichte der Sprachwissenschaft 1. 185-191.

Swiggers, P. 1991b. "Variation, Invariance, Hierarchy, and Integration as Grammatical

Parameters". L.R. Waugh - S. Rudy eds., New Vistas in Grammar: Invariance and Variation, 185-220. Amsterdam: J. Benjamins.

Swiggers, P. 1993. "'Synchrony' and 'Diachrony' in Sapir's Language (1921)". Neuphilologische Mitteilungen 94. 313-322.

Swiggers, P. 1995. "How Chomsky Skinned Quine, or What 'Verbal Behavior' can do". Language Sciences 17. 1-18.

Vendryes, J. 1921. Le langage. Introduction linguistique à l'histoire. Paris: Renaissance du Livre.

Wells, R.S. 1947. "Immediate Constituents". Language 21. 321-343. 


\section{JEZIKOVNE TEORIJE V DVAJSETEM STOLETJU EPISTEMOLOŠKA DIAGNOZA}

Namen sestavka je analitično obdelati glavne epistemološke konfiguracije jezikoslovja v dvajsetem stoletju. Prva konfiguracija, ki je obravnavana, je Saussurjeva jezikovna teorija, ki je osredinjena na znak in ki postavlja trditev, da je jezikoslovje del bolj obsežne teorije znakov, namreč semiotike. Naslednjo konfiguracijo, ki je obravnavana, tvorijo ravninske jezikoslovne teorije, npr. Bloomfieldov, Harrisov in Hockettov strukturalizem. Te teorije se navezujejo na instrumentalistično epistemologijo jezikoslovja; poudarjajo vlogo klasifikacije, ki izhaja iz oblike, in prisegajo na poenoten program znanstvenega opisa. Tretja glavna konfiguracija je tvorbeno-pretvorbena slovnica, ki je v začetku temeljila na predpostavki o avtonomni skladnji. V tem modelu ostaja vprašljivih več teoretičnih načel, tako psihološka realnost slovničnih pravil in izkustvena vsebina univerzalne slovnice. V zadnjih letih se ta model srečuje $z$ odporom spoznavoslovnih teorij. V luči teh ključnih napetosti je jasno, da bo jezikovna teorija morala primerno epistemologijo šele izdelati. 